\title{
Immunoglobulin Superfamily Member 8
}

National Cancer Institute

\section{Source}

National Cancer Institute. Immunoglobulin Superfamily Member 8. NCI Thesaurus. Code C74516.

Immunoglobulin superfamily member 8 ( $613 \mathrm{aa}, \sim 65 \mathrm{kDa}$ ) is encoded by the human IGSF8 gene. This protein is involved in the regulation of cellular proliferation and motility. 